Motivation underpins successful tennis performance, representing one of the game's foremost psychological skills. This paper elaborates on its role in tennis play, and takes an overview of the current state of motivation research applied to tennis. First, the importance of motivation in player and coach performance is explored. The body of evidence pertaining to players' motives for participation and the relevance of goal achievement motivation in tennis is then examined. Finally, the efficacy of motivational climates created by significant others is discussed in light of current practice.

See end of article for authors' affiliations

....................

Correspondence to: Miguel Crespo, International Tennis Federation, Development/ Coaching Department, C/ Tirso de Molina, 21, 6-21, 46015, Valencia, Spain; dualde@xpress.es

Accepted 26 June 2007 Published Online First 22 June 2007
T ennis is a sport that requires different psychological skills. Motivation is one of those skills. Tennis, unlike many other sports, has no substitutes, no time-outs, no in-game coaching and often in tournaments, no second chance. Throughout, players must adapt their games to ever-changing playing conditions (ie, court surfaces, altitudes, balls, competition systems, etc.) and many different opponents. With this in mind, it becomes clearer why motivation, underpinned or supported by related concepts (ie, drive, passion, persistence, competitiveness, effort, and desire to participate and win), is important to all stages of player development. Interestingly, despite the seemingly prominent role of motivation in tennis, no review has combined the associated literature nor summarised its application to tennis coaching and play. In this article, the importance of motivation in tennis, motives for participation, goal achievement motivation, and motivational climates will be discussed.

\section{IMPORTANCE OF MOTIVATION}

Several studies have surveyed players and coaches regarding the most important psychological skills and strategies needed for tennis play. ${ }^{1-3}$ The consensus among tennis coaches pointed to enjoyment and fun, together with motivation and passion, self-confidence, positive thinking/selftalk, positively managing mistakes, focus/concentration, emotional control, honesty/integrity, practice intensity, and keeping competition in perspective as being the game's most critical mental skills and strategies in ranked order, and of even greater importance among developing $\left(<14\right.$ years) players. ${ }^{12}$ Interestingly, when coaches working with junior players were asked to list the most difficult mental skills to teach, motivation featured prominently. ${ }^{12}$

When compared to coaches, young players responded similarly in identifying the mental skills key to tennis success. That is, motivation as well as love and interest in tennis rated highly, while selfconfidence, self-control, determination, commitment, and concentration were also considered important for successful tennis performance. ${ }^{5}$ A higher level of goal achievement motivation was found among professional top players when compared to junior players. ${ }^{6}$ Goal achievement motivation, understood as a driving force in tennis play, was also shown to be a crucial factor in the development of talented junior players. ${ }^{7}$ Although more research is needed to establish the significance of motivation among different tennis playing populations, indications are that it is important for all those involved in the game.

\section{MOTIVES FOR PARTICIPATION}

Evaluation of the motives for young players' participation in tennis is a feature of contemporary tennis psychology studies. Research has revealed the main motives that underpin young tennis players' initial involvement in the sport. ${ }^{5}{ }^{8}$ These include: increasing playing level, keeping physically fit, enhancing skills and making new friends. Less important motives as perceived by young players were: satisfying parents or friends, feeling important, being popular and earning rewards and prizes. Gender-based differences pointed to boys preferring competition, challenge, status, entertaining and rewards more so than girls, while older players ( $\geqslant 12$ years) were shown to be motivated by being popular, using tennis equipment, the company of friends and satisfying parents to a greater extent than players aged under 12 years of age. Noteworthy is that establishing a good rapport with the coach, and perceiving their roles positively, were of greater importance to younger players $(<12$ years) than to older players. In light of this, it can generally be concluded that reasons for participation are mainly intrinsic, that extrinsic motivation increases with age, and that factors such as age, gender and club atmosphere influence motivation. ${ }^{5} 89$

With respect to different playing populations, comparable amounts of perceived competence, intrinsic motivation and performance-oriented motives have been reported among beginner and intermediate players. As might be expected, selfmotivation and parental involvement have also been shown as influential in children "taking up" tennis. ${ }^{10-12}$ Motives for adult tennis participation range from a desire to keep healthy and maintain mobility to the game's perceived psycho-social benefits. ${ }^{13}$ Indeed, with adult players participating for these reasons, it comes as little surprise that they have further been shown to score higher in vigour, optimism and self-esteem but lower in depression, anger, confusion, anxiety and tension 
than other athletes and non-athletes. ${ }^{14}$ Significantly, similar findings have been noted to distinguish frequent wheelchair tennis players from less regular or inactive wheelchair athletes. ${ }^{15}$ Participation-oriented programmes such as the International Tennis Federation's "Play and Stay" campaign and the French Tennis Federation's "adult tennis" programme have embraced some of the above research findings and are designed to retain as many players as possible by ensuring a positive and active introductory tennis experience. ${ }^{16-17}$

\section{GOAL ACHIEVEMENT MOTIVATION}

Goal perspective theory is one of the modern approaches to understanding motivation in tennis. This theory states that task-involved individuals define personal competence in terms of self-referenced standards such as task effort, skill improvement, and learning, whereas ego-involved individuals assess their own competence based on norm-referenced criteria such as outperforming others and demonstrating superior ability with minimal effort. ${ }^{18}$

As task-involvement emphasises self-referenced standards, individuals adopting this goal perspective have a greater capacity to develop and maintain appropriate competence perceptions within a particular achievement setting such as tennis. It is important to note, however, that a player's level of perceived competence in a physical domain does not necessarily ensure a particular goal perspective. ${ }^{19}$ Nevertheless, when applied to tennis, this theory suggests that task-orientation is positively related to adolescent players' interest in tennis, their perceived importance of the sport, and the effort they exert while playing; and that ego-orientation relates to heightened worry and impaired concentration. ${ }^{19}$

Newton and Duda ${ }^{20}$ revealed that undergraduate recreational players, lower in ego-orientation and confident in winning their matches, were more inclined to believe that effort and not external factors (ie, luck) would lead to tennis success. By contrast, elite adolescent ego-oriented players were found to consider their ability and their need to maintain a positive image as the primary causes of success. ${ }^{21}$

The relationships between goal orientation and intrinsic motivation have been investigated, with some research consensus linking task-oriented undergraduate tennis players to higher levels of intrinsic motivation. ${ }^{22}$ A task-involving goal perspective has also been associated with the selection of more challenging tasks, the use of more self-referenced resources of competence, and with better performance in college beginner and high school players. ${ }^{23}{ }^{24}$ Interestingly, a recent study on the relationship between goal orientation and outcome of a forehand stroke indicated that this orientation might not be an influential characteristic in the learning process of college beginner tennis players, but a reflection of the evaluation of their success. ${ }^{25}$ Task-orientation has also been shown to positively correlate with enjoyment and fun in the practices of able-bodied and wheelchair tennis players. ${ }^{26}$

Research has further shown that the development of task and ego goals in elite junior tennis players rests on a complex interaction of factors, such as cognitive-developmental skills and experiences, the motivational climate conveyed by significant others, the structural and social nature of the game and the match context. ${ }^{27}{ }^{28}$ Specific major predictors of taskinvolvement for these players were reported as the perceptions of significant others, the achievement value of the match and the perceptions of ability. The intensity of ego-involvement prematch was predicted by ego-orientation combined with perceptions of significant others as well as the match value. ${ }^{29}$

To summarise, the application of goal achievement motivation to tennis supports the notion that players' goal perspectives influence their tennis playing and training behaviours.

\section{MOTIVATIONAL CLIMATE IN TENNIS}

The motivational climate is the goal structure of the training and competition situation perceived by the players. This climate is created by significant others and it prevails in tennis lessons, just as it can at players' homes. Only recently has the study of the impact of significant others (coach, parents, peers) on player motivation attracted research attention. Children and adolescents develop their preferences for task- and ego-oriented goals through repeated interactions with significant others such as coaches, parents and peers. They also perceive a situational goal structure in tennis, which is largely created by these same individuals. As with individual motives, the terms task- and ego-oriented are also applied to describe motivational climates in tennis. ${ }^{30}$

Players high in task-orientation and who perceive a taskinvolving tennis environment have been observed as less likely to report psychological withdrawal from tennis and suffer burn-out. These types of environments are considered to reinforce effort, directing players to focus on the processes and intrinsic rewards of learning and improving, as well as group co-operation and cohesiveness. Ego-involved motivational climates, on the other hand, are noted to emphasise results and outcomes, often recognising the work of only talented players, fostering rivalry within the team or squad, and greeting mistakes with forms of punishment. ${ }^{31-33}$ Certainly, in specific tennis settings, where ego-involved climates prevail, players have reported greater devaluation by coaches and teammates. $^{30}$

Various player surveys have unveiled that task-oriented motivational climates foster strong work ethics and higher perceived competence, while also positively predicting selfconfidence, improvement, satisfaction, player enjoyment, sportpersonship, persistence and effort. Players were further shown to display higher satisfaction with their coaches and fellow players as well as reduced anxiety responses and "thoughts of escape". An ego-involving climate was revealed to promote out-doing others and achieving without effort, detract from player enjoyment, decrease player satisfaction with their coaches and increase feelings of pressure (somatic and cognitive anxiety) with deteriorating tennis performance. $^{34-38}$

General indications are thus that motivational climate in tennis becomes more ego-involved as players move from beginner to competition tennis, reinforcing the need for researchers to consider the importance of dispositional and situational variables when predicting goal involvement in competitive contexts. That is, at the beginner level, taskoriented motivational climates are important to enhance player motivation and enjoyment. At advanced levels, an egoinvolving motivational climate might precipitate, yet coaches should be task-involving in their interactions with players during training and before and after competition. ${ }^{18}$

In summary, the above-mentioned evidence-based support for task-oriented learning environments suggests that coaches, parents and significant others should, where possible, create such environments. To do so, and therefore foster positive motivational patterns in players, issues such as the meaning of success to players, how coaches explain success and failure to players, the reactions from coaches and parents to the mistakes or bad performances of players, the role of extrinsic factors in player training, and the player self-esteem should be addressed. ${ }^{39}$ Proposed methods to promote more rewarding task-involving environments among others include the use of optimal challenge to match individual skill level and drill difficulty (eg, adapting drills and equipment), stimulating (eg, using a wide variety of drills) and more co-operative rather than competitive practices, emphasis on effort and the learning 


\section{What is already known on this topic}

- Tennis requires different psychological skills. Motivation and related concepts (ie, passion, persistence, competitiveness, and effort) are important to all stages of player development.

- Players define personal competence by combining task and ego orientations. Parents and coaches create a motivational climate that influences players' performance.

\section{What this study adds}

This review succinctly integrates motivational research in tennis from performance and participation perspectives.

and development of new skills, helping players set individual, realistic and measurable short-term performance goals that are based on improvement and effort, player leadership and involvement in decision-making by providing them some autonomy in drill selection during practices, and flexible and heterogeneous grouping arrangements. ${ }^{40}{ }^{41}$ Indeed, these methods represent some of the core coaching recommendations, advanced by the International Tennis Federation together with other tennis nations, to foster efficacious motivational climates for players. ${ }^{39}$

\section{CONCLUSIONS}

The current review has underlined the key role of motivation in tennis play. Motivation and its related concepts, enjoyment, fun, passion and love for the game, have ranked very high in importance for successful tennis performance by coaches and players alike. Research exploring the motives for player participation has highlighted improving performance, keeping physically fit and socialising as the main reasons for different individuals' involvement in the sport. Feeling important and popular, and earning rewards represented less important motives, while club atmosphere and having a good rapport with the coach also influenced player participation.

Contemporary goal achievement motivation research in tennis provides general support for the promotion of a taskoriented goal perspective in players. The value of task-involving motivational climates, particularly at the beginner level, has been similarly evidenced. However, future work that examines the efficacy of strategies that foster these perspectives and climates, among different playing populations, is eagerly anticipated.

\section{ACKNOWLEDGEMENTS}

The authors would like to thank the International Tennis Federation for their assistance in this project.

\section{Authors' affiliations \\ Miguel Crespo, International Tennis Federation, Valencia, Spain \\ Machar M Reid, University of Western Australia, Perth, Australia}

Funding: This study was supported by the International Tennis Federation. Competing interests: None declared.

\section{REFERENCES}

1 Gould D, Medberry R, Damariian N, et al. A survey of mental skills training knowledge, opinions, and practices of junior tennis coaches. J App/ Sport Psychol 1999;11:28-50.

2 Gould D, Damariian N, Medberry R. An examination of mental skills training in junior tennis coaches. Sport Psychol 1999;13:127-43.

3 Moran A. How effective are psychological techniques used to enhance performance in tennis? The views of some international tennis coaches. In: Reilly $\mathrm{T}$, Hughes $M$, Lees $A$, eds. Science and racket sports. London: EFN \& Spon, 1994:221-5.

4 Terry P. Mental training for junior tennis players resident at the Rover LTA School Bisham Abbey 1987-1993: issues of delivery and evaluation. In: Reilly T, Hughes $M$, Lees A, eds. Science and racket sports. London: EFN \& Spon, 1994:212-20.

5 Balaguer I, Atienza F. Principales motivos de los jóvenes para jugar al tenis. Apunts 1994;31:285-99.

6 Butt D, Cox D. Motivational patterns in Davis Cup, university and recreational tennis players. Int J Sport Psychol 1992;23:1-13.

7 Unierzyski P. Level of achievement motivation of young tennis players and their future success. J Sport Sci Med 2003;2:184-6.

8 Puig J, Villamarín F. Motivación y autoeficacia durante la iniciación deportiva en tenis. In: Cantón E, compiler. Actas V Congr Nac Psicol Act Fís y Deporte. Valencia: Universitat de Valencia, 1995:103-109.

9 González G, Tabernero B, Márquez S. Análisis de los motivos para participar en fútbol y en tenis en la iniciación deportiva. Rev Esp Ed Física Deportes 1999;6:12-23.

10 Lesko S. Perceived competence and intrinsic motivation among junior tennis players [MSc dissertation]. Springfield College, Springfield, Massachusetts, 1992.

11 Baxter-Jones A, Maffulli N. Parental influence on sport participation in elite young players. J Sports Med Phys Fitness 2003:43:250-5.

12 Hyllegard R, Radlo S, Early D. Attribution of athletic expertise by college coaches. Percept Mot Skills 2001;92:193-207.

13 Kolt G, Driver R, Giles L. Why older Australians participate in exercise and sport $J$ Aging Phys Act 2004; 12:185-98.

14 Finn J, Axtell, J, Kemler D, et al. Profile of mood states among senior tennis players. In: USTA National Conference on Sports Medicine and Science in Tennis; April 28-May 1, 1993. Tampa, Florida: USTA, 1993.

15 Muraki M, Tsunawake S, Hiramatsu S. The effect of frequency and mode of sports activity on the psychological status in tetraplegics and paraplegics. Spinal Cord 2000;38:309-14.

16 ITF. Tennis Play and Stay. http://www.tennisplayandstay.com (accessed 13 February 2007).

17 FFT. Programme Adultes. Paris: French Tennis Federation, 2003.

18 Duda J. The implications of the motivational climate in tennis. In: Crespo M, Reid M, Miley D, eds. Top tennis coaching. London: ITF Ltd, 2001:55-8.

19 Newton M. Duda J. Tennis is not a matter of life and death, it is much more important than that - the relationship between dispositional goal perspectives and effort, interest, involvement and trait anxiety in adolescent tennis players. RQES 1992;63:1112.

20 Newton M, Duda J. Relations of goal orientations and expectations on multidimensional state anxiety. Percept Mot Skills 1995;81:1 107-12.

21 Newton M, Duda J. Elite adolescent players' achievement goals and beliefs concerning success in tennis. J Sport Exerc Psychol 1993;15:437-448.

22 Duda J, Chi L, Newton M, et al. Task and ego orientation and intrinsic motivation in sport. Int J Sport Psychol 1995;26:40-63.

23 Solmon $M$, Boone J. The impact of student goal orientation in physical education classes. RQES 1993;64:418-24.

24 Williams L. Goal orientations and athletes' preferences for competence information sources, J Sport Exerc Psychol 1994;16:416-30.

25 Berlant A. Weiss M. Goal orientation and the modeling process: an individual's focus on form and outcome. RQES 1997;68:317-30.

26 Cervelló E, Fuentes J, Sanz D. Un estudio piloto de las características motivacionales de los tenistas y de los tenistas en silla de ruedas en competición. Apunts. Educación Física y Deportes 1999;58:73-8.

27 Harwood C, Swain A. The development and activation of achievement goals in tennis: I. Understanding the underlying factors. Sport Psychol 2001;15:319-41.

28 Harwood C, Swain A. The development and activation of achievement goals in tennis: II. A player, parent and coach intervention. Sport Psychol 2002;16:111-38.

29 Harwood C, Swain A. Antecedents of pre-competition achievement goals in elite junior tennis players. J Sports Sci 1998;16:357-71

30 Duda J, Balaguer I, Moreno Y, et al. The relationship of the motivational climate and goal orientations to burn-out among junior elite tennis players. In: Conference proceedings of the Association for the Advancement of Applied Sports Psychology. Denton, Texas: RonJon Publishing, 2001.

31 Balaguer I, Guivernau M, Duda J, et al. Análisis de la validez de constructo y de la validez predictiva del Cuestionario de Clima Motivacional Percibido en el deporte (PMCSQ-2) con tenistas españoles de competición. Rev Psicol Deporte 1997; 11:41-59.

32 Balaguer I, Duda J, Crespo M. Motivational climate and goal orientations as predictors of perceptions of improvement, satisfaction and coach ratings among tennis players. Scand J Med Sci Sports 1999;9:381-8.

33 Kavussanu M, Roberts G. Motivation in Physical activity contexts: the relationship of perceived motivational climate to intrinsic motivation and self-efficacy. J Sport Exerc Psychol 1996; 18:264-80.

34 Cervelló E, Santos-Rosa F, Jiménez R, et al. Motivación y ansiedad en jugadores de tenis. Rev Motricidad 2002;9:141-61 
35 Yi-Hsu W, Chien-Chih C, Mei-Yao H, et al. The effects of different tennis teaching models on perceptions of learning environment and learning outcomes of tennis in college physical education. Poster presentation, AAHPERD National Convention and Exposition, Chicago, 12-16 April 2005

36 Hatzigeorgiadis A, Biddle S. The effects of goal orientation and perceived competence on cognitive interference during tennis and snooker performance. J Sport Behav 1999;22:479-501.

37 Yoo J. Motivational climate and perceived competence in anxiety and tennis performance. Percept Mot Skills 2003;96:403-13.
38 Fry $M$, Newton M. Application of achievement goal theory in an urban youth tennis setting. JASP 2003:15:50-66.

39 Crespo M, Reid M, Quinn A. Tennis psychology. London: ITF Ltd, 2006.

40 Harwood C, Biddle S. The application of achievement goal theory in youth sport. In: Coackerill I, eds. Solutions in sport psychology. London: Thompson Learning, 2002:58-73.

41 Cervelló E, Santos-Rosa F, García Calvo T, Jiménez R, Iglesias D. Young tennis players' competitive task involvement and performance: the role of goal orientations, contextual motivational climate, and coach-initiated motivational climate. J Appl Sport Psychol 2007;19:1-18.

\section{BMJ Clinical Evidence-Call for contributors}

BMJ Clinical Evidence is a continuously updated evidence-based journal available worldwide on the internet which publishes commissioned systematic reviews. BMJ Clinical Evidence needs to recruit new contributors. Contributors are healthcare professionals or epidemiologists with experience in evidence-based medicine, with the ability to write in a concise and structured way and relevant clinical expertise.

Areas for which we are currently seeking contributors:

- Secondary prevention of ischaemic cardiac events

- Acute myocardial infarction

- MRSA (treatment)

- Bacterial conjunctivitis

However, we are always looking for contributors, so do not let this list discourage you.

Being a contributor involves:

- Selecting from a validated, screened search (performed by in-house Information Specialists) valid studies for inclusion.

- Documenting your decisions about which studies to include on an inclusion and exclusion form, which we will publish.

- Writing the text to a highly structured template (about 1500-3000 words), using evidence from the final studies chosen, within 8-10 weeks of receiving the literature search.

- Working with BMJ Clinical Evidence editors to ensure that the final text meets quality and style standards.

- Updating the text every 12 months using any new, sound evidence that becomes available. The BMJ Clinical Evidence in-house team will conduct the searches for contributors; your task is to filter out high quality studies and incorporate them into the existing text.

- To expand the review to include a new question about once every 12 months.

In return, contributors will see their work published in a highly-rewarded peer-reviewed international medical journal. They also receive a small honorarium for their efforts.

If you would like to become a contributor for BMJ Clinical Evidence or require more information about what this involves please send your contact details and a copy of your CV, clearly stating the clinical area you are interested in, to CECommissioning@bmigroup.com.

\section{Call for peer reviewers}

BMJ Clinical Evidence also needs to recruit new peer reviewers specifically with an interest in the clinical areas stated above, and also others related to general practice. Peer reviewers are healthcare professionals or epidemiologists with experience in evidence-based medicine. As a peer reviewer you would be asked for your views on the clinical relevance, validity and accessibility of specific reviews within the journal, and their usefulness to the intended audience (international generalists and healthcare professionals, possibly with limited statistical knowledge). Reviews are usually 1500-3000 words in length and we would ask you to review between 2-5 systematic reviews per year. The peer review process takes place throughout the year, and our turnaround time for each review is 10-14 days. In return peer reviewers receive free access to BMJ Clinical Evidence for 3 months for each review.

If you are interested in becoming a peer reviewer for BMJ Clinical Evidence, please complete the peer review questionnaire at www.clinicalevidence.com/ceweb/contribute/peerreviewer.jsp 